\title{
Lektioita
}

\author{
Katharina Koch ${ }^{\mathbf{a}}$
}

\section{Re-thinking the potential of cross-border cooperation for security}

\author{
Lectio Praecursoria of Doctoral Dissertation \\ University of Oulu, 6.6.2018
}

Borders have the potential to protect you against threats. At least, this is what you may think when you hear the word "border" and imagine its implications on your own life but also for the state and its society. However, after a while, you may realize that borders also create potential threats by posing harm to the society, to its freedom, and its wellbeing by restricting movement and interaction. International relations and politics attempt to alleviate such possible harmful restrictions of borders by implementing cross-border cooperation policies. It is this - to a more or lesser extent - institutionalized organization of trans- and cross-border relations that is creating interdependence between states and is supposed to minimize the risk of wars and conflicts.

Therefore, cross-border cooperation, from a post-modern perception, forms an important policy tool for states to promote economic and social exchange while at the same time increasing the perception of national security for its population. This has been also recognised by the European Union, which, in 2004, developed the European Neighbourhood Policy (ENP). This policy formally includes the entire EU external border regions that are reaching from the Arctic Ocean to the Mediterranean Sea. The diversity of these border regions poses geographical and political - in short - geopolitical - challenges for the EU. One single policy cannot address all the challenges and recognise the specific circumstances of each cross-border region that marks the territorial boundaries of the European Union.

The title of my thesis is "The Geopolitics of Cross-Border Cooperation". However, where to start an analysis of geopolitics? What questions need to be asked? Critical Geopolitics is conceptualised as the understanding of how intellectuals of statecraft construct ideas about places (O’Tuathail \& Agnew 1992). These ideas reinforce political behaviour and, as a result, affect our own ideas towards places and politics. Critical geopolitics has started to incorporate the study of borders in the early 1990s and utilises concepts such as territory, state, space and scale to understand borders in the 21 st century. All of these concepts are very familiar for human and in particular political geographers. 
The focus of my thesis is directed towards understanding the border as a "process" (c.f. Paasi 1999) which has helped me to study the meaning of the Finnish-Russian border in the context of cross-border cooperation (CBC) that is funded by the European Neighbourhood Instrument (ENI). Conceptualisations and theorisations of borders have been recognised as a key element of political geography, for example in the context of territory and territoriality (see Sack 1986). The study of borders in geography dates back as far as the late 19th century in which scholars traditionally focused on the evolution and development of the territorial lines that demarcate modern nation-states. This perspective has changed drastically since the late 1980s, which were generally demarcated by the development of post-modern research approaches across the human and social sciences.

Today we understand borders from a multitude of perspectives and different sociospatial contexts that have to be considered in the study of borders. This has also shifted our analytical research lens away from the border as a line. Instead, our goal is to investigate the socially constructed meanings and mindscapes of the actors participating in boundarydrawing practices (O’Tuathail \& Dalby 1998) which have de- and re-bordering effects (Popescu 2012). Borders reflect a site at and through which socio-spatial differences are communicated. But why study borders? What is so important about them?

Perhaps, a bit of background on recent political developments can help to clarify these questions. In 2001, the Schengen rules came into force. These removed internal border controls within the EU. At the same time, however, we experienced a strengthening of the EU external border controls. While EU and Schengen citizens and visa-holders enjoy free movement across the internal borders, the EU external borders have gradually turned into a death trap for many who try to cross them without valid documentation. Already since the early 2000s and the beginning of the ENP, academics have been defining the EU as a "Fortress". The EU external borders are considered as an insurmountable barrier for many people, as we have seen in 2015 during the so-called 'refugee-crisis', which has claimed the lives of thousands attempting to enter EU territory. These external borders - paired with the EU border security policies - sparked my interest and led to this research. However, what makes the EU external borders so different? What are the EU's and member state's interests in them? How does the EU aim to govern them and with which strategy?

I mentioned in the beginning that critical geopolitics aims to analyse foreign policy and international political behaviour. Throughout my research, which I began in early 2014, the political circumstances were quite different compared to the global geopolitical situation we are experiencing nowadays. The empirical focus of my doctoral thesis is directed towards the Finnish-Russian border. Consequently, Finnish-Russian and EU-Russian diplomatic relations have been of a particular significance for my research. In early 2014, the Ukrainian crisis gradually deteriorated EU-Russia relations. The consequences of this crisis are apparent until nowadays. I believe that many of you remember, for example, the oversupply of cheese that was intended for the Russian market in Finnish supermarkets. This was only one direct consequence of the economic sanctions after which the exports of goods produced in the EU were restricted into Russia. Tourism numbers declined as well. Finnish businesses reported a decline of Russian tourists because incomes in Russia were cut by up to $50 \%$ during the economic crisis (Shkurov 2017). Economic sanctions, introduced by the EU and Russia in summer 2014, almost ended EU funded FinnishRussian cross-border cooperation. Rigorous lobbying in Brussels, led by the Finnish former Prime Minister, in close coordination with the Finnish regional councils and other EU member states, prevented the inclusion of Finnish-Russian cross-border cooperation into the EU's sanctions list.

While Finnish-Russian cross-border cooperation continues and tourism from Russia to Finland is increasing once more, the hopes of a stabilisation of EU-Russia relations were recently once more shattered. The poisoning of the former Russian military intelligence officer and his daughter in London on the 4th of March 2018, led to numerous evictions 
of Russian diplomats across the world. Furthermore, just some weeks ago, Russian President Vladimir Putin, triumphantly, crossed the new bridge connecting Russia and the Crimean Island, marking another event in the long process of displaying occupational control and Russian influence on the Crimean Island and in Ukraine. In light of this particular geopolitical security environment, the main research question of this thesis is the following: How does the discourse on 'stable' borders, as formulated by the cooperation actors at various governmental levels, securitise cross-border cooperation?

As I have mentioned, my research has been greatly influenced by the challenging geopolitical situation between the EU and Russia. How do these circumstances connect to my research? How does it affect the Finnish, Russian and other EU actors who are working in the cooperation programmes? How does it affect the perception of the border for these actors and influence the security agenda of the EU for its neighbourhood? These are only some of the questions that I have strived to answer with each of my publications. This thesis builds on a multi-dimensional research approach that studies the geopolitics of cross-border cooperation in the context of Finland and Russia. More specifically, I focus my question on the security dimension of Finnish-Russian cross-border cooperation that is funded by the EU. In this way, my aim was to identify to which extent EU external crossborder cooperation contributes to or even transforms into a security strategy promoting stable and secure EU external borders. The research method I have employed builds on a multi-dimensional approach which is based on the utilization of various empirical materials. I have collected relevant policy documents, held interviews, viewed and listened to public speeches and studied information material. This has generated a rich set of data which I have discussed using a critical geopolitical approach. This particular approach has allowed me to pay attention and to identify the asymmetrical power relations between the cooperation actors that are subject to the continuous influence of territorial frictions and resistance. At the same time, my thesis contributes to the post-modern security understanding.

The EU external borders cannot only be secured using traditional military and surveillance approaches. Instead, my thesis shows that the perception of security increases by establishing close cooperation between neighbouring states that are based, for example, on trust, effective border-crossing facilities, common regional identity and a non-hierarchical cooperation network. My research results suggest that the region-building efforts promoted by the EU in the Finnish-Russian cross-border programmes; the multilevel governmental network of cooperation; and the establishment and maintenance of trust between the cooperation actors, contribute to the EU external border security strategy.

Furthermore, territorial and national agendas continue to influence the cooperation actors which was proven by the near exploitation of the EU funded cooperation projects as leverage against Russia because of its actions in Ukraine. As a result, scholars have been arguing that the promoted "partnership" character of EU external cross-border cooperation is in reality yet based on "assistance" to maintain stability in the neighbourhood (see Khasson 2013). For example, the communication between the Finnish and Russian actors is overshadowed by territorial elements, such as the bureaucratic hurdles to utilise EU funding in Russian projects as well as administrative challenges that derive directly from the border that underlies the Schengen Information System requirements. Nevertheless, cross-border cooperation operates within a relational network of actors and in this way, without discarding the importance of the state, this thesis follows a relational approach to territoriality by recognising the state's continuous significance in the cooperation network. At the same time, it pays attention to the actions of the Finnish sub-national actors within the cooperation programmes.

The results suggest that, in particular, Finnish sub-national actors, who are working in the joint management authorities of the Finnish-Russian cooperation programmes, have 
developed strategies to overcome the territorial frictions that result out of, for example, the challenging geopolitical environment between the EU and Russia (Koch 2017).

I hope that I could highlight for you the importance of studying, analysing and questioning the functions and effects of borders and cross-border cooperation. We often tend to recognise cross-border cooperation as a soft policy tool, which promotes prosperous exchange between neighbours. However, my research also discloses the underlying aspects that continue to influence actor relations and are serving EU - and Russian - geopolitical interests. When I started my research in 2014, we could not anticipate the global changes we have seen during the last four years and which have influenced the public and political discourse on the internal and external EU borders. The so-called "refugee crisis" in summer 2015, has not only led to changes of national legislation regarding internal security and migration policies, but also spiked the election results of populist parties across the EU and the world. Furthermore, on the 24th of June 2016, the unprecedented happened - a slight majority of the United Kingdom's population voted to leave the European Union.

Two years later, politicians and experts are still struggling to comprehend this process and trying to find a way to prevent the creation of an external border within Ireland. This would mean throwing us 500 years back into history, effectively separating the republic and the kingdom, Catholicism and Protestantism. It means ripping open old wounds of gentrification and segregation - which had deadly results in the past. These reflect just a few of the future challenges that border scholars are facing at the moment and which they have to find ways to incorporate into empirical and conceptual studies.

The challenges that border scholars face at the moment seem to increase. In November 2016, Donald Junior Trump was elected as the 45th president of the United States of America. His approach to win the election was to promote the construction of a border wall between the US and Mexico. All the while, these political and international developments, which - I have to emphasize - only erupted within the last four years, battered diplomatic international relations. And not only that, Europe and the EU are shaken almost every month by terror attacks, sparking fear, insecurity, and anger towards refugees whose presence in Europe have been exploited by populist parties to spread their arguments of exclusion against immigrants and foreigners. By now border scholars are certain that the praised - "borderless world" - of the 1990s has not become reality. Instead, we see a strengthening of borders, national identity, state territorial control and the almost desperate attempts of political leaders to maintain sovereignty over state territory. However, with my thesis, I hope to contribute to the knowledge of our relational territorial world. I do not suggest that the influence of the state is vanishing, neither are territorial factors that are battering international relations. What my research does is to show that, despite the dire geopolitical circumstances, we are witnessing today, cooperation actors are finding effective ways and offering solutions to resist against the once more increasing territoriality of states that threaten the sensitive balance of diplomatic relations that was achieved within Europe after the collapse of the Soviet Union.

\section{References}

Khasson V. (2013) Cross-border cooperation over the Eastern EU border: between assistance and partnership under the European neighbourhood and partnership instrument. East European Politics 29(3) 328-343. $<$ https://doi.org/10.1080/21599165.2013.807802

Koch, K. (2018) The spatiality of trust in EU external cross-border cooperation. European Planning Studies 26(3) 591-610. <https://doi.org/10.1080/09654313.2017.1393502>

O’Tuathail, G. \& Agnew, J. (1992) Geopolitics and Discourse. Practical geopolitical reasoning in American foreign policy. Political Geography 11(2) 190-204. < https://doi.org/10.1016/0962-6298(92)90048-X>

O’Tuathail, G. \& Dalby, S. (1998) Introduction: Rethinking geopolitics: towards a critical geopolitics. In O’Tuathail, G. \& Dalby, S. (eds.) Rethinking geopolitics, 1-15. Routledge, London. 
Paasi, A. (1999) Boundaries as social practice and discourse: The Finnish-Russian border. Regional Studies 33(7) 669-680. <https://doi.org/10.1080/00343409950078701>

Popescu, G. (2012) Bordering and Ordering the Twenty-first Century: Understanding Borders. Rowman \& Littlefield Publishers, Plymouth.

Sack RD (1986) Human Territoriality: Its Theory and History. Cambridge University Press, Cambridge.

Shkurov, S. (2017). What's up in Russian travel to Finland, Sergei Shkurov? < http://www.visitfinland.fi/ news/whats-up-in-russian-travel-to-finland-sergei-shkurov/>. 15.06.2018.

\section{Information of the doctoral thesis}

Katharina Koch: Geopolitics of Cross-border Cooperation at the EU's External Borders: Discourses of de- and re-bordering, territorial perceptions and actor relations within the Finnish-Russian ENI cooperation network. Nordia Geographical Publications, 47:1/2018. ISBN: 978-952-62-1962-2 ISSN: 1238-2086. Geography Research Unit, University of Oulu, Oulu 2018.

https:// nordia.journal.fi/article/view/71008 